Adam Lityński (Sosnowiec)

\title{
Rewizjonistyczna historia rewolucji rosyjskiej i stalinowskiego terroru. Na kanwie książki Sheili Fitzpatrick „Rewolucja rosyjska"1
}

Sheila Fitzpatrick jest historyczką australijską, okresowo wykładała w Londynie i Chicago; napisała wiele prac z dziejów Związku Radzieckiego, zwłaszcza okresu stalinowskiego, i dwie jej książki zostały już wcześniej przetłumaczone na język polski². Należy do grupy sowietologów rewizjonistów i nawet uważana jest za jedną z liderek tej grupy. Obecne wydanie polskie jest thumaczeniem czwartego wydania przygotowanego - jak pisze Autorka - w Australii przy wsparciu współpracowników z Uniwersytetu w Sydney. To daleko od nas, daleko od Rosji, daleko od bolszewików. I tę odległość widać w całej treści książki. To trochę jak z innej planety. Zza Bugu widzi się to lepiej. Rzecz bynajmniej nie w jakiejś nieznajomości faktów, lecz w duchu tej książki - eseju o skutkach rosyjskiej rewolucji 1917 roku. Eseju napisanego pięknym językiem (i pięknie przetłumaczonego), co intensyfikuje sugestywność dyskursu.

Przed kilku laty Edward Acton, znany brytyjski profesor Uniwersytetu Wschodniej Anglii, autor wielu poważnych prac dotyczących zwłaszcza dwudziestowiecznej historii Rosji, czyli przede wszystkim rewolucji rosyjskiej i dalszych jej skutków, drugie wydanie swojego dzieła o historii Rosji XX wieku zaczął z nad wyraz trafnym samokrytycyzmem. Pierwsze zdanie książki E. Actona

${ }^{1}$ S. Fitzpatrick, Rewolucja rosyjska, tłum J. Bożek, Wydawnictwo Krytyki Politycznej, Warszawa 2017, ss. 229.

2 Życie codzienne pod rzadami Stalina. Rosja radziecka w latach trzydziestych XX wieku, tł. J. Gilewicz, Kraków 2012; Zespót Stalina. Niebezpieczne lata radzieckiej polityki, przeł. K. Iwaszkiewicz, Wołowiec 2017.

3 E. Acton, Dziedzictwo caratu i władzy radzieckiej, thum. J. Stawiński, Warszawa 2013, s. 11. 
brzmi: „Rosja jest krajem w wielu aspektach niepojętym dla zachodni e go u my słu" [podkreślenie moje-AL]. I ma rację. Sheila Fitzpatrick też powinna była tak napisać. Autorka wpisuje się swą interesującą książką w ,zachodni umysł”, a ten punkt widzenia jest inny niż nasz.

We wstępie Autorka pisze, że w prezentowanym czwartym wydaniu książki akcentuje szczególnie trzy motywy. „Pierwszy to modernizacja, rewolucja jako środek do ucieczki od zacofania. Drugi to klasa, rewolucja jako misja proletariatu i jego »awangardy«, czyli partii bolszewickiej. Trzeci to przemoc rewolucyjna $\mathrm{i}$ terror, rewolucyjna metoda na rozprawienie się z wrogami, i jej znaczenie dla partii bolszewickiej i radzieckiego państwa" (s. 18). Recenzentowi - człowiekowi który urodził się na wschód od Bugu, cudem zbiegł stamtąd już w 1940 roku i później przeżył 45 lat pod sowieckim zwierzchnictwem między Bugiem a Odrą - wśród priorytetów książki Sheili Fitzpatrick wielce brakuje zwłaszcza imperialnego charakteru tego państwa. Wszak skutkiem rewolucji było także siłowe ujarzmienie jakże licznych narodów i sowietyzowanie ich nie tylko w drodze nachalnej propagandy, lecz także przez fizyczne likwidowanie ich warstwy przywódczej. Katynia zapomnieć się nie da w naszym miejscu na ziemi, ale z Australii go nie widać. Autorka czyni wprawdzie zastrzeżenie, że „również czwarte [wydanie] jest historią rewolucji rosyjskiej pisaną przede wszystkim z perspektywy Rosji, a nie terytoriów wchodzących w skład dawnego Imperium Rosyjskiego czy Związku Radzieckiego" (s. 23). Recenzent uważa jednak, że czynienie zastrzeżenia o takim ograniczeniu pola obserwacji jest po prostu naukowym błędem. Tak nie wolno, bo w ten sposób historia rewolucji rosyjskiej m u s i b y ć z a fa 1 $\mathrm{s} \mathrm{z} \mathrm{o} \mathrm{w} \mathrm{an} \mathrm{a.} \mathrm{Obok} \mathrm{innych} \mathrm{zafałszowań} \mathrm{wynikających} \mathrm{z} \mathrm{przemilczeń,} \mathrm{o} \mathrm{czym}$ będzie jeszcze mowa, tak ogromny obszar naukowego przemilczenia stanowi naukowy błąd najpoważniejszy.

Obok wspomnianych trzech wątków Sheila Fitzpatrick we wprowadzeniu do głównych wywodów szczególną uwagę poświęciła zagadnieniu interpretacji okresu trwania rewolucji. Termin a quo dla Autorki nie ulega wątpliwości (to rewolucja lutowa 1917 r.), ,ale kiedy skończyła się rewolucja rosyjska? Czy w październiku 1917 roku, gdy bolszewicy sięgnęli po władzę A może wraz ze zwycięstwem bolszewików w wojnie domowej w 1920 roku? Czy »odgórną rewolucję« Stalina [chodzi o zakończenie NEP-u - A.L.] należy postrzegać jako część rewolucji rosyjskiej? A może rewolucja trwała, dopóki istniało państwo radzieckie? (...) Ostatnie pytanie dotyczy wielkiej czystki z lat 1937-1938 - czy i ona należała do rewolucji rosyjskiej?" (s. 9, 11). I Autorka konkluduje, że wskazane zakręty historii to "odrębne epizody dwudziestoletniego procesu rewolucyjnego" i w konsekwencji zakreśla: „W tej książce czas trwania rewolucji rosyjskiej sięga więc od lutego 1917 roku do wielkiej czystki z lat 1937-1938” (s. 12). Recenzent 
dopowie, że zgadza się to z całym - bogatym - dorobkiem naukowym sowietolog-rewizjonistki, który w zasadzie nie sięga poza ,niemiecką inwazję i w s t ę p do udziału Sowietów w II wojnie światowej” (s. 12, podkr. A.L). My w Polsce dramatycznie doświadczeni skutkami paktu Ribbentrop-Mołotow - nie możemy naukowo tolerować nawet lapsusów takich, jak akceptowanie sowieckiego punktu widzenia, iż II wojna zaczęła się 22 czerwca $1941 \mathrm{r}$. To zresztą nie jest sprawa tylko Polski, lecz całej Europy Środkowo-wschodniej od Morza Barentsa do Morza Czarnego, a wydane w 80-lecie zbrodniczego paktu oświadczenie ministrów spraw zagranicznych pięciu krajów tej części Europy dowodzi, że to boli narody, a nie tylko niżej podpisanego recenzenta.

Jak już wspomniano, esej Sheili Fitzpatrick dobrze się czyta i dopóki na kartach nie pojawiają się bolszewicy, budzi tylko uznanie zarówno za treść, jak i formę wykładu, nawet tak lakonicznego, jak fragment o wojnie japońsko-rosyjskiej i rewolucji 1905 r. A była to rewolucja ważna, bo to pierwsza w Rosji rewolucja ludowa, która przyniosła i zostawiła w spadku tworzenie prawdziwie ludowych rad miejskich oraz bunty żołnierzy, w tym marynarzy. Jedno i drugie odżyje wszak w kilkanaście lat później.

Przechodząc do roku 1917, Autorka słusznie pisze, że „Lenin i inni uchodźcy polityczni przebywający w neutralnej Szwajcarii niecierpliwie zbierali się do drogi" (s. 66). Racja, ale to obraz nieco uproszczony. Przywódcy Socjaldemokratycznej Partii Robotniczej Rosji (bolszewików) [SDPRR(b)] byli zaskoczeni wybuchem rosyjskiej rewolucji. Deportowany z Europy Trocki właśnie (w styczniu 1917) zamieszkał w Bronksie, zaś Lenin z towarzyszami przebywał w Szwajcarii i w tym samym czasie wygłosił odczyt, w którym wyraził przekonanie, że „my, starzy, nie dożyjemy być może decydujących bitew tej nadciągającej rewolucji”" Zdecydował się wracać do Rosji, gdy dotarły do niego wieści o abdykacji cara. Wówczas przyjął propozycje niemieckiego wywiadu i kontrwywiadu, wziął od nich poważne kwoty ${ }^{5}$ oraz skorzystał ze zorganizowanego przez Niemców tajnego przejazdu przez Skandynawię do Helsinek. Do Piotrogrodu przybył w kwietniu 1917 r.; Trocki w maju. „Niemcy bardzo sprytnie przesłali te zjadliwe zarazki choroby, od której może paść cała Rosja, jak przewidywał Hall. Według niego był to zapewne środek skuteczniejszy od gazów trujących czy broni bakteriologicznej, gdyź środek ten stanowi zarazki nieuchwytne, atakujące nie ciało, ale mental-

${ }^{4}$ Cyt. za L. Kołakowski, Główne nurty marksizmu. Powstanie, rozwój, rozkład, Londyn 1988, s. 746; zob. też L.D. Trocki, Moje życie. Próba autobiografii, tłum. J. Barski, S. Łukomski, Warszawa 1930 [druk anastatyczny Warszawa 1990], s. 299 i n.; M. Occleshaw, Za kulisami rewolucji bolszewickiej, tłum. K. Bażyńska-Chojnacka, P. Chojnacki, Warszawa 2007, s. 57.

${ }^{5}$ Zob. bliżej R. Pipes, Krótka historia rewolucji rosyjskiej, tłum. W. Jeżewski, Warszawa 2007, s. 115; idem, Rewolucja rosyjska, tłum. T. Szafar, Warszawa 1994, s. 329; A. Andrusiewicz, Kiereński-czerwony liberat, Warszawa 2016, s. 169-170. 
ność i duszę ludzką. Wysłańcami okazali się Władimir Lenin, Radek, Łunaczarski i Lew Bronstein-Trocki" ${ }^{-}$- po latach pisał we wspomnieniach Mieczysław Jałowiecki, litewsko-rosyjsko-polski arystokrata i aktywny uczestnik wydarzeń. Winston Churchill miał powiedzieć to samo w Izbie Gmin: „Lenin został wysłany do Rosji w taki sam sposób, jak wysyła się fiolkę zawierającą bakterie tyfusu lub cholery"7. Ujawnione przyjęcie pieniędzy na działalność wywrotową od wojennego wroga Rosji wywołało oskarżenia o zdradę. W czasie wojny za to się rozstrzeliwało. Na Lenina i jedenastu innych bolszewików wydano nakaz aresztowania. Lenin zbiegł do Helsinek. Autorka ze zwykła sobie swadą lakonicznie napisała, że „rewolucjoniści musieli rozważyć, czy ich powrót jest wart ryzyka kompromitacji politycznej" i Lenin podjął to ryzyko (s. 66).

Wątek nazwany przez Autorkę modernizacją, rewolucją jako środkiem ucieczki od zacofania, poprowadzony został zgrabnie od drugiej połowy XIX stulecia, co najmniej od lat 70. XIX wieku, od czasu gdy narodnicy - młodzi rosyjscy inteligenci - najpierw poszli w lud, a gdy ta misja okazała się zupełnym fiaskiem, poszli w rewolucyjny terroryzm, wykazując przy tym heroizm, nie szczędząc własnego życia. Wszystko dlatego, że kochali Rosję (to Rosjanie) i chcieli ją zmodernizować. Sheila Fitzpatrick pisze o tym ładnie, ubiera ten wykład w formę autorskiego eseju.

Polski recenzent chce w tym miejscu od siebie dodać kilka uwag o polskim udziale, motywowanym nie dążeniem do modernizacji Imperium, lecz do obalenia caratu jako ciemiężyciela Polski. Od czasu, gdy (1878) Wiera Zasulicz, działaczka rewolucyjna Narodnej Woli, dokonała zamachu rewolwerowego na gradonaczalnika Petersburga Fiodora Trepowa, a sąd przysięgłych - ku osłupieniu kręgów władzy - wydał wyrok uniewinniający ${ }^{8}$, terrorystyczne zamachy rewolucjonistów z Narodnej Woli mnożyły się i musiała pojawić się idea carobójstwa. Jak wiadomo, 1 (13) marca 1881 roku dokonano zamachu bombowego na cara Aleksandra II. Skutecznie rzucał Polak - student Ignacy Hryniewiecki. Samobójczo. Obaj zmarli. Petersburscy terroryści rozszerzyli kontakty z innymi organizacjami, zwłaszcza z rozmaitymi polskimi grupami socjalistycznymi w Wilnie, gdzie trafili do Bronisława Piłsudskiego, starszego brat Józefa Klemensa. Policję car zmodernizował najszybciej i ta nie próżnowała. Na lawie oskarżonych, ramię w ramię, zasiedli starszy brat przyszłego Lenina ze starszym bratem przyszłe-

\footnotetext{
${ }^{6}$ M. Jałowiecki, Na skraju Imperium i inne wspomnienia, Warszawa 2017, s. 329.

7 W.H. Carrol, Narodziny i upadek rewolucji komunistycznej, thum. A. Żabokrzycki, Kąty Wrocławskie 2008, s. 77; por. też A. Lityński, Prawo Rosji i ZSRR 1917-1991 czyli historia wszechzwiązkowego komunistycznego prawa (bolszewików). Krótki kurs, wyd. 3, Warszawa 2017, s. 27.

${ }^{8}$ Bliżej zob. E. Radziński, Aleksander II. Ostatni wielki car, tłum. E. Siemaszkiewicz i R. Śliwowski, Warszawa 2005, s. 303 i n.
} 
go Naczelnika Państwa II RP. Na szubienicy, względnie w Szlisselburgu albo na katordze na Sachalinie (Bronisław Piłsudski), kończyli coraz liczniejsi działacze Narodnej Woli (m.in. Polacy). Na szubienicy zawisł także Aleksander Ilicz Uljanow, starszy brat Włodzimierza; zaś Włodzimierz właśnie przystępował do matury w rodzinnym Symbirsku, gdzie dyrektorem szkoły był Fiodor Michajłowicz Kiereński, a młodszym kolegą szkolnym Włodzimierza Uljanowa był syn Fiodora Michajłowicza - Aleksander Kiereński, w 1917 r. premier Rządu Tymczasowego obalonego przez Lenina. Świat jest mały, ale Australia jednak daleko.

Wizja Autorki rewolucji w Rosji jako ścieżki ucieczki od zacofania jest trafna zarówno z punktu widzenia ustrojowo-politycznego, jak i gospodarczego, chociaż w tej drugiej sprawie jeszcze przed Wielką Wojną postęp istotny w Rosji osiągnięto. W ostatniej dekadzie XIX w. produkcja przemysłowa Imperium Rosyjskiego rosła szybko; w liczbach względnych. Powstawały lokalnie wielkie zakłady-giganty przemysłowe, z których największym były Zakłady Putiłowskie ${ }^{9} \mathrm{w}$ Petersburgu. Rozwinęło się kolejnictwo, ważne w tym wielkim kraju ${ }^{10}$; Wielka Magistrala Transsyberyjska ${ }^{11}$ miała być konkurencją dla Kanału Sueskiego. W każdym razie Sheila Fitzpatrick zgrabnie wywodzi korzenie dążenia do modernizacji z XIX wieku. Po rewolucji 1917 roku i po okresie wojny domowej przyjęcie NEP-u to „zdyscyplinowany odwrót” od dotychczasowego sposobu prowadzenia gospodarki (tzw. komunizmu wojennego). Subiektywnie recenzent wyczuwa u Autorki żal, że w latach NEP-u „obywatele musieli też płacić za wcześniej darmowe usługi publiczne, jak szkolnictwo i opieka zdrowotna; ograniczono im też dostęp do emerytur, rent oraz zasiłków dla bezrobotnych, wprowadzając przymusowe oskładkowanie" (s. 121). Takie gładkie sformułowania w podtekście sugerują czytelnikowi jakieś pogorszenie w zakresie prawa pracy. Recenzent uważa, że w tym miejscu należało coś powiedzieć, jak wyglądało bolszewickie ,prawo pracy".

9 Od nazwiska Nikołaja Iwanowicza Putiłowa (1820-1880), szlachcica, absolwenta Morskiego Korpusu Kadetów, właściciela tych zakładów, które na zlecenie cara podjęły się budowy okrętów; później rozbudowywane, m.in. produkowały szyny kolejowe, na które było duże zapotrzebowanie wobec rozwoju kolejnictwa.

${ }^{10}$ W XX wiek Rosja wkraczała jako drugi kraj na świecie pod względem długości linii kolejowych. J. Sobczak, Mikołaj II - ostatni car Rosji. Studium postaci i ewolucji władzy, Warszawa 2009, s. 250.

${ }^{11}$ Niebywałym osiągnięciem była zwłaszcza Transsyberyjska Kolej, Transsyberyjska Magistrala, Wielka Magistrala Syberyjska: jedna z najdłuższych na świecie linii kolejowych, łączy europejską część Rosji z Syberią i Dalekim Wschodem; zbudowana w latach 1895-1916; długość 9332 km, nie licząc odgałęzień; biegnie z Moskwy przez Omsk, Irkuck, Chabarowsk do Władywostoku; dwutorowa; z odgałęzieniem do Mongolii i Chin; obecnie zelektryfikowana. Panowanie nad gigantycznym obszarem Syberii zależało ówcześnie przede wszystkim od panowania nad koleją transsyberyjską. 
Wszak po rewolucji bolszewickiej i likwidacji własności prywatnej przestawał istnieć wolny najem pracy, a w to miejsce miał być wprowadzony ,jednaki przymus pracy dla wszystkich, utworzenie armii przemysłowych, zwłaszcza dla rolnictwa” - stwierdzali twórcy programu komunistycznego ${ }^{12}$. „Kto nie pracuje, ten nie je" - głosił Manifest komunistyczny, a powtarzał to Lenin ${ }^{13}$. Powszechny obowiązek pracy wprowadziła Deklaracja praw ludu pracujacego $i$ wyzyskiwanego (25 stycznia 1918) $)^{14}$, która następnie weszła w skład (art. 18) pierwszej konstytucji RSFRR (10 lipca 1918), co później było kontynuowane w konstytucji stalinowskiej $(1936)^{15}$. Praca w komunizmie nie miała być motywowana bodźcami materialnymi, lecz samym entuzjazmem ${ }^{16}$. „,...) sama zasada pracy przymusowej jest dla komunisty niepodważalna (...). Jedynym rozwiązaniem trudności ekonomicznych, poprawnym zarówno z punktu widzenia praktyki, jak zasady jest traktować ludność całego kraju jako rezerwuar koniecznej siły roboczej (...)"wywodził Trocki. Konieczna jest militaryzacja pracy; państwo pracy ,jest upoważnione, by posyłać każdego robotnika tam, gdzie jego praca jest potrzebna"17. Przymus w państwie totalitarnym miał być więc totalny. Masowy przymus wymagał masowego terroru, co ujawniło się i utrwaliło po kilku względnie spokojnych latach NEP-u.

Ogłoszono (10 grudnia 1918) kodeks pracy ${ }^{18}$, będący kompilacją wcześniejszych unormowań; kodeks ustanowił prawo do pracy, ale także przewidywał przymus pracy, co miały realizować rady przez pociąganie „burżuazji” do wykonywania prac fizycznych na rzecz wojska, wyrębu lasów na opał, prac załadunkowych itp.; wprowadzono (5 października 1918) specjalne książki pracy dla takich

12 K. Marks, F. Engels, Manifest komunistyczny, Warszawa 1983, s. 87.

13 W. Lenin, Państwo i rewolucja, w: tenże, Dzieła, t. 33, Warszawa 1987, s. 89.

${ }^{14}$ История советской конституции. Сборник документов. 1917-1957, Издательство Академии Наук СССР, Москва 1957, s. 44-46; История советской конституции (в документах) 1917-1956, Государственное издательство юридической литературы, Москва 1957, s. 57-59.

${ }_{15}$ Zob. P. Fiedorczyk, A. Lityński, A. Stawarska-Rippel, Wojny XX wieku i ich skutki dla ustrojów państwowych i prawa, „Czasopismo Prawono-Historyczne” 2019, t. LXXI, z. 1, s. 79.

${ }^{16}$ Praca komunistyczna - wywodził Lenin - ,jest to bezpłatna praca na rzecz społeczeństwa, praca wykonywana nie ze względu na określoną powinność, nie w celu otrzymania prawa do określonych produktów (...), wynikająca z nawyku do pracy dla dobra ogółu i oparta na świadomym stosunku (który stał się nawykiem) do niezbędności pracy dla dobra ogółu (...)”. Cyt. za A. Walicki, Marksizm i skok do królestwa wolności. Dzieje komunistycznej utopii, Warszawa 1996, s. 357; zob. też idem, Zarys myśli rosyjskiej. Od oświecenia do renesansu religijno-filozoficznego, Kraków 2005, s. 687.

17 Cyt. za L. Kołakowski, Główne nurty marksizmu..., s. 775.

18 Собрание Узаконений и Распоряжений Рабочего и Крестьянского Правительства РСФСР. 1918. № 87/88. Ст. 905; zob. też История отечественного государства и права, ч. 2, (ред.) О.И. Чистяков, Москва 2006, s. 138. 
osób $^{19}$. Z wielu jednostek czerwonoarmistów tworzono armie pracy ${ }^{20}$. Na mocy uchwały KC RKP(b) (22 stycznia 1920) o militaryzacji proletariatu przemysłowego wprowadzono militaryzacje grup potrzebnych gospodarce; przeprowadzono ją w trzech etapach do początku $1921 \mathrm{r}^{21}$ Najpierw Radę Obrony Robotniczej i Chłopskiej przekształcono w Radę Pracy i Obrony, a w grudniu 1919 r. przy Radzie Pracy i Obrony powołano Główny Komitet do Spraw Obowiązku Pracy na czele z Trockim. Komitet realizował zadania m.in. ustanowienia armii pracy i wprowadzenie w przemyśle oraz rolnictwie zasad wojskowej dyscypliny - militaryzacji pracy ${ }^{22}$. Komitet i jego metody funkcjonowały do końca $1921 \mathrm{r}^{23} \mathrm{~W}$ latach NEP-u wprowadzono zwykłe umowy o pracę i ułatwiono (tylko ułatwiono) zmianę miejsca pracy ${ }^{24}$. W latach II wojny światowej (po 22 czerwca 1939 r.) wrócono do militaryzacji pracy oraz przedłużono czas pracy ${ }^{25}$. Przymus pracy mieścił się w filozofii komunistycznej, toteż pojawiał się on w rozmaitych aktach prawnych. Nie sposób omówić tu całości zagadnień pracy w ZSRR, ale w pełni wolny rynek pracy pojawi się dopiero w końcowym okresie pieriestrojki, po nowelizacjach prawa pracy od $1988 \mathrm{r}^{26}$

Naukową ślepotą byłoby jednak poruszanie zagadnień pracy w ZSRR bez przynajmniej sygnalizacji pracy niewolniczej więźniów Gułagu. Zagadnienie pracy w ZSRR trzeba rozpatrywać łącznie z pracą przymusową łagierników, która przez dziesięciolecia stanowiła nader ważny element gospodarczy i społeczny kraju. Stalinowskie przejście do wyższego stadium budowy komunizmu, likwi-

${ }^{19}$ N.G. Aleksandrow (red.), Radzieckie prawo pracy, tłum. J. Licki i J. Dąbrowski, Warszawa $1951 \ldots$, s. 91; История отечественного государства и права, ч. 2.., s. 139.

${ }^{20}$ Historia Wszechzwiązkowej Komunistycznej Partii (bolszewików). Krótki kurs, pod red. komisji KC WKP(b), Warszawa 1948, s. 271.

${ }^{21}$ O. Subbotin, Das sowjetische Arbeitsrecht zwischen den Weltkriegen 1917-1941, [w:] T. Giaro [hrsg], Modernisierung durch Transfer zwischen den Weltkriegen, Frankfurt am Main 2007, s. 109; zob. też История отечественного государства и права, ч. 2..., s. 139.

${ }^{22}$ Przykładowo, Lenin w piśmie do członków Rady Obrony Robotniczo-Chłopskiej 1 lutego 1920 r. nakazywał: „Sytuacja w transporcie kolejowym jest wręcz katastrofalna. Dowóz zboża został przerwany. Aby się uratować, potrzebne są środki naprawdę nadzwyczajne. (...) Zmniejszyć obecny przydział chleba dla niepracujących w transporcie; zwiększyć dla pracujących. Niech nawet zginą jeszcze tysiące, ale kraj będzie uratowany. (...) po obydwóch stronach linii kolejowych wprowadzić stan wojenny w celu mobilizacji do pracy nad oczyszczaniem torów (...)". W. Lenin, Dzieła, t. 40, Warszawa 1988, s. 79.

${ }^{23}$ И.А. Исаев, История государства и права России, 4-е издание, Москва 2016, s. 575, 581, 688; zob. też Энииклопедия государства и права, t. 3, (ред.) П. Стучка, Москва 1930, s. 931; История отечественного государства и права, ч. 2.., s. 222.

${ }^{24}$ История отечественного государства и права, ч. 2,.., s. 223.

${ }_{25}$ Radzieckie prawo pracy..., s. 110; Ф.М. Левиант, А.С. Пашков, Трудовое право, [w:] Сорок лет советского права 1917-1957, том 2, Ленинград 1957, s. 318; История отечественного государства и права, ч. 2.., s. 337-339.

${ }_{26}$ История отечественного государства и права, ч. 2..., s. 470-472. 
dacja NEP-u, kolektywizacja, industrializacja oraz wprowadzenie centralnego planowania pięcioletniego skutkowały także realizacją wcześniejszych koncepcji szerokiego wykorzystania pracy więźniów. Rada Komisarzy Ludowych podjęła (11 lipca 1929) uchwałę określającą na dziesiątki lat kierunek rozwoju systemu miejsc uwięzienia i wykorzystywania więźniów: o wykorzystaniu pracy więźniów przy kolonizacji odlegtych rejonów ZSRR i eksploatacji tamtejszych bogactw naturalnych. „W celu skolonizowania” odległych rejonów ZSRR „i eksploatacji ich bogactw naturalnych" zdecydowano o utworzeniu sieci poprawczych obozów pracy OGPU ${ }^{27}$ o nazwie ITŁ ${ }^{28}$, zaś uchwałą Rady Komisarzy Ludowych z 7 kwietnia 1930 r. powołany został organ kierujący systemem obozowym OGPU, a mianowicie Zarząd Obozów OGPU, w kilka miesięcy później przemianowany na Zarząd Główny Obozów OGPU ${ }^{29}$ - GUŁag ${ }^{30}$.

Zapowiadany przez Stalina ,wielki skok” gospodarczy sam w sobie nie mógł zapewnić racjonalnego wykorzystania pracy więźniów. Przejście z wolnego rynku na centralne planowanie skutkowało - od 1931 r. - zmianą zadań OGPU w zakresie administrowania łagrami. Łagry nie miały odtąd być tylko dostawcą siły roboczej, lecz plany stawiały przed każdym łagrem samodzielne zadania gospodarcze, a w związku z tym ustalano „limity” zaopatrzenia, w tym limity siły roboczej, czyli planowano liczbę więźniów. Nie planowano rentowności, lecz wykonywanie planu. Po wybuchu wojny niemiecko-radzieckiej ${ }^{31}$ (22 czerwca 1941 r.) drastycznie wzrosła śmiertelność w obozach i koloniach karnych: z kilkuprocen-

${ }^{27} 6$ lutego 1922 r. Czeka została zreorganizowana w Państwowy Zarząd Polityczny - GPU [Государственное Политическое Управление - Gosudarstwiennoje Politiczeskoje Uprawlenije] a ten (na krótko) został włączony w struktury ludowych komisariatów spraw wewnętrznych. Kiedy 30 grudnia 1922 r. podpisany został układ o utworzeniu ZSRR, GPU przemianowano na OGPU Zjednoczony Państwowy Zarząd Polityczny [Обединённое Государственное Политическое Управление - Objedinionnoje Gosudarstwiennoje Politiczeskoje Uprawlejnije). Wkrótce potem (6 lipca 1923) OGPU wyłączono ze struktur republikańskich komisariatów spraw wewnętrznych. OGPU uzyskało status zarządu związkowego (czyli ogólnopaństwowego); podlegało bezpośrednio rządowi ZSRR, czyli Radzie Komisarzy Ludowych ZSRR.

${ }^{28}$ Исправительно-трудовой лагерь - isptrawitielno-trudowoj łagier.

${ }^{29}$ M. Jacobson, M. Smirnow, System miejsc uwięzienia w RFSRR i ZSRR w latach 1917-1930, [w:] N. Ochotin i A. Rogiński (red.), Łagry. Przewodnik encyklopedyczny, tłum. R. Niedzielko, Warszawa 1998, s. 19, passim; M. Smirnow, S. Sigaczow, D. Szkapow, System miejsc uwięzienia w ZSRR w latach 1929-1960, [w:] ibidem, s. 27, passim.

${ }^{30}$ Pełna nazwa brzmiała: Zarząd Główny Poprawczych Obozów i Kolonii Pracy $=$ Главное Управленийе Исправительно-Трудовой Лагерьей и Колоний - Gławnoje Uprawlenije Isprawitielno-Trudowych Łagierej i Kołonij = GUŁag.

31 Wówczas (1942) z łagrów wyszła i opuściła Związek Radziecki największa grupa więźniów Gułagu w dziejach tej instytucji: byli to Polacy ,amnestionowani” 12 sierpnia 1941 r. na mocy układu polsko-radzieckiego, którzy wyszli z „nieludzkiej ziemi” z tzw. armią Andersa. Przywieziony przez tysiące Polaków materiał był przerażający i wręcz porażający. „,...) materiał zebrany w kwestionariuszach i nieco powierzchowne badania historyczne [Polaków] przez pół wieku były niemal 
towej do 25\% uwięzionych; w 1942 r. zmarło 351360 więźniów. Przyczyn należy upatrywać w pogorszeniu zaopatrzenia żywnościowego. W końcowym okresie wojny i po zakończeniu działań wojennych znacznie wzrosła populacja GUŁ-agu. Wyłączając jeńców wojennych, liczba uwięzionych w 1950 r. (apogeum) przekraczała 2800000 osób. Jeńcy wojenni ${ }^{32}$ natomiast nie znajdowali się w administracji Gułagu; obozy jenieckie tworzyły odrębną strukturę administracyjną. Od 1949 do marca 1953 r. miała miejsce największa ekspansja systemu przymusowej pracy więźniów, a jednocześnie są to lata postępującego kryzysu systemu: spadku wydajności siły roboczej ${ }^{33}$.

Za tymi liczbami, danymi, nazwami przecież kryły się życie i los ludzi. Milionów ludzi. Ile wart jest człowiek, zapytała w swoich wspomnieniach Rosjanka, która przeżyła 20 lat w łagrze ${ }^{34}$. I trzeba jej odpowiedzieć, że w tym systemie nic nie był wart. Ale takiego obrazu ZSRR i takiej odpowiedzi próżno szukać w książce Sheili Fitzpatrick.

Rewolucja jako misja proletariatu - drugi z ważnych dla Sheili Fitzpatrick wątek rozważań - nie budzi zastrzeżeń w warstwie filozoficznej, gdy pisze, że bolszewicy sądzili, iż ,ideologia naukowego socjalizmu uodporniła ich na myślenie utopijne” (s. 106). Tym bardziej zgodzić się trzeba, że „nieuchronność rewolucji również była artykułem wiary" (s. 106). Recenzent widzi tutaj jednak potrzebę połączenia warstwy filozoficznej z wydarzeniami historycznymi, ze sferami polityki i militarną. Wszak rewolucję bolszewicy koniecznie chcieli roznieść na cały świat i w miarę swoich sił bezpośrednio po podpisaniu rozejmu w lasku Compiègne usiłowali to uczynić. W istocie wszak w tym celu po 11 listopada 1918 r. ruszyli, by „po trupie Polski” rewolucję zanieść co najmniej - w pierwszej fazie - do podminowanych komunizmem Niemiec. I tutaj już nie da się uciec od aspektów imperialnych pochodu Armii Czerwonej na zachód po traktacie brzeskim oraz po zakończeniu Wielkiej Wojny. Wszak w celach imperialnych bolszewicy 13 listopada 1918 r. (data wypowiedzenia przez nich traktatu brzeskiego) wszczęli w istocie drugą część Wielkiej Wojny. Teraz toczyła się ona tylko na wschodzie Europy oraz południu (Kaukazie Północnym i Zakaukaziu) i doszła do Wisły w sierpniu 1920 r. Tak wyglądała misja proletariatu.

jedynymi namacalnymi dowodami istnienia Gułagu" i jego geografii. A. Applebaum, Gułag, thum. J. Urbański, Warszawa 2005, s. 418.

32 Szacunkowe liczby dotyczące jeńców wojennych przedstawiają się następująco (dane na początek roku): 1946 r. - 2400 - 2700 tysięcy; 1947 r. - 1800 tysięcy; 1948 r. - 1200 tysięcy; 1949 r. - 550 tysięcy; 1950 r. - 37 tysięcy; 1953 r. - 19 tysięcy. M. Smirnow, S. Sigaczow, D. Szkapow, System miejsc uwięzienia w ZSRR w latach 1929-1960..., s. 51.

${ }_{33}$ M. Smirnow, S. Sigaczow, D. Szkapow, System miejsc uwięzienia w ZSRR w latach 1929 $1960 \ldots$, s. 46-49, passim.

${ }^{34}$ J. Kiersnowska, Ile wart jest czlowiek, thum. W. Karaczewska, E. Niepokólczycka, E. Rojewska-Olejarczuk, Warszawa 2012. 
Sheila Fitzpatrick - chociaż zastrzegła na wstępie ograniczenie swojej książki do „perspektywy Rosji” - w jakże skromnym zakresie (s. 89) dotyka zagadnień polityki „nowej Republiki Radzieckiej” względem narodowości nierosyjskich, czyniąc tak w aspekcie granic terytorialnych Republiki (s. 89). Ledwie pół zdania Autorka poświęciła, by stwierdzić, że „przed wojną Lenin ostrożnie aprobował zasadę samostanowienia narodów" i że czynił tak ze względów pragmatycznych. ,Jednak samostanowienie narodów miało granice, co uwidoczniło się przy włączaniu do nowej republiki radzieckiej terytoriów wchodzących w skład wcześniejszego imperium" (s. 89). To jest właśnie rewizjonizm historii bolszewizmu: nie można temu zaprzeczyć, ale jakże te zgrabne, miło brzmiące sformułowania fałszują brutalną rzeczywistość „czerwonego” imperializmu. Lenin zaś nie dopuszczał myśli o oderwaniu się od Rosji narodów nierosyjskich; nie uważał za możliwe, by Rosja się rozpadła ${ }^{35}$. Rację ma R. Pipes, gdy stwierdza, że w ciągu kilku miesięcy „po abdykacji cara kwestia narodowa wysunęła się na czoło zagadnień rosyjskiej polityki"36. Po rewolucji lutowej ruchy narodowe w byłym Imperium Rosyjskim narastały z niespodziewaną szybkością ${ }^{37}$. Zauważmy, że bolszewicy robili rewolucję z hasłami w pierwszym rzędzie społecznymi, bo taki przecież był ich program, ale od pierwszych tygodni przyszło im zmierzyć się przede wszystkim z problemami narodowymi. Zauważmy jeszcze więcej: dokładnie z tymi samymi problemami przyszło zmierzyć się białym. Tylko czerwoni zgrabniej się za nie zabrali oszukując wszystkich, a tego biali nie chcieli robić.

Wskazywałem już ${ }^{38}$, wspierając się zresztą na poważnej literaturze naukowej, że pojmowanie dziejów ludzkości jako historii permanentnej walki klas skutkowało usuwaniem problemów narodowych w cień tejże walki klasowej, diametralnie im przeciwstawnej ${ }^{39}$. „Zarówno Marks, jak Engels uważali, że małe państwa słowiańskie we wschodniej Europie są anachroniczne (...), opowiadali się za wielkimi mocarstwami, centralizmem (...)" ${ }^{\prime 40}$. Problemy narodowości u Marksa i Engelsa, a w konsekwencji u marksistów, Robert Conquest uzna za „obszar

${ }^{35}$ M. Waldenberg, Kwestie narodowe w Europie Środkowo-Wschodniej. Dzieje. Idee, Warszawa 1992, s. 251.

${ }^{36}$ R. Pipes, Czerwone imperium. Powstanie Zwiazku Sowieckiego, thum. W. Jeżewski, Warszawa 2015 , s. 52.

${ }^{37}$ M. Heller, [w:] M. Heller, A. Niekricz, Utopia u władzy. Historia Związu Sowieckiego, thum. A. Mietkowski, t. 1, Wrocław 1989, s. 55.

38 A. Lityński, Między ,, białym” a ,czerwonym” imperium. Rzecz o narodach w Rosji 19171922, Sosnowiec 2018, s. 17-18.

39 M. Waldenberg, Kwestie narodowe..., s. 191; R. Pipes, Czerwone imperium ..., s. 23.

${ }^{40}$ R. Pipes, Czerwone imperium..., s. 22; zob. też A. Walicki, Marksizm i skok do królestwa wolności. Dzieje komunistycznej utopii, Warszawa 1996, s. 323; J. Smaga, Narodziny i upadek imperium. ZSRR 1917-1991, Kraków 1992, s. 38 i n. 
zaślepienia" i przytacza na to dowody ${ }^{41}$. Rację ma M. Heller, gdy zauważa, że w kwestii narodowej program partii bolszewickiej „był prawdziwie marksistowski”, ponieważ ,zawierał dwie wzajemnie wykluczające się zasady: samostanowienia narodów i scentralizowanego państwa” ${ }^{42}$. „Federalizm w Rosji (...) odegra rolę przejściową - do przyszłego socjalistycznego unitaryzmu"43 - kreślił wizję Stalin, a po bolszewickim zamachu stanu to on został szefem Narkomnacu ${ }^{44}$. Tymczasowo zaś w sposób mistrzowski rozwiązano dylemat tworząc republiki posiadające na papierze duży zakres własnej władzy, natomiast centralizację przeprowadzono przez jedną partię komunistyczną zorganizowaną na modłę wojskową; to „centralizm demokratyczny” - dwa słowa wzajemnie się wykluczające. To jeden z elementów totalnego kłamstwa, jak by to powiedział Leszek Kołakowski. Ale tego w omawianej książce Sheili Fitzpatrick nie ma.

„Rewolucja Stalina” to najobszerniejszy z rozdziałów książki. Na wysokim poziomie erudycji i intelektu Sheila Fitzpatrick prowadzi rewizjonistyczny wywód poświęcony zwłaszcza okresowi po 1929 roku, bez wyraźnej daty końcowej, ale na pewno sięgającej co najmniej 1933 roku. W nader inteligentnej formie splecione zostały tutaj takie wątki, jak likwidacja NEP-u, industrializacja, kolektywizacja, rozkułaczanie, walka z opozycją wewnątrzpartyjną, a także wzmianki

${ }^{41}$ R. Conquest, Uwagi o spustoszonym stuleciu, thum. T. Bieroń, Poznań 2002, s. 88.

${ }^{42}$ M. Heller, [w:] M. Heller, A. Niekricz, Utopia u władzy..., s. 66.

${ }_{43}$ J. Stalin, Dzieła, t. 4, Warszawa 1951, s. 83.

${ }^{44}$ W pierwszym rządzie bolszewików (Radzie Komisarzy Ludowych) utworzono specjalnie dla Stalina nieznany dotychczas resort - Komisariat do Spraw Narodowości (Народный Комиссариат по Делам Национальностей, skrot: Наркомнац - Narkomnac). Komisariat do Spraw Narodowości miał w swojej strukturze sekcje/oddziały do spraw określonych narodów: litewski, łotewski itd., ale pierwszą taką sekcją była polska (zwana Komisariatem do Spraw Polskich; Sekcji-Komisariatu do Spraw Polskich nie należy mylić z utworzonym nieco później (9 lipca 1919) Polskim Biurem KC Rosyjskiej Komunistycznej Partii (bolszewików), w składzie z m.in. Dzierżyńskim. W kompetencji Komisariatu było przygotowywanie decyzji o ustanawianiu lub likwidowaniu republik i obwodów autonomicznych i struktur ich organów; w istocie zakres działania jego był nieograniczony. „Komisariat podjął starą politykę rusyfikacji” prowadzoną z Moskwy (И.А. Исаев, История государства и права..., s. 632, 671). Od maja 1920 r. Komisariat miał swojego przedstawiciela w każdej republice, a republiki sowieckie wysyłały w skład Komisariatu swoich przedstawicieli; ci zaś wraz z kierownikami oddziałów Narkomnacu utworzyli organ pod nazwą Rady Narodowości. Po wprowadzeniu w życie konstytucji z 1924 r. Narkomnac został zlikwidowany, ponieważ zastąpiła go reprezentująca republiki i okręgi autonomiczne Rada Narodowości. A. Lityński, Prawo Rosji i ZSRR 1917-1991 ..., s. 400 і n.; История советской конституиии. Сборник документов. 1917-1957..., s. 221; История советской конституции (в документах) 1917-1956..., s. 424; Энииклопедия государства и права, (ред.) П. Стучка, Издательство Коммунистической Академии, Москва 1930, t. 2, s. 858; W. Suchecki, Geneza federalizmu radzieckiego, Warszawa 1961, s. 91; szczegółowo zob. K. Zieliński, O Polska Republikę Rad. Działalność polskich komunistów w Rosji Radzieckiej 1918-1922, Lublin 2013, s. 24 i n., 76 i n., passim. 
o pokazowych procesach sądowych elit specjalistów kierujących gospodarką ${ }^{45}$. Nie ma tutaj miejsca, by skomentować szczegóły wypowiedzi, ale recenzentowi zabrakło na przykład uwag o ideologicznej warstwie likwidacji NEP-u. NEP dawał okazję bogacenia się niektórym (szczególnie chłopom), zaś człowiek zamożny w znacznym stopniu staje się niezależny od władzy. Od totalitarnej władzy zaś nikt nie mógł być niezależny; to przeczyłoby istocie totalitaryzmu ${ }^{46}$. Tylko chłop będący robotnikiem w uspołecznionym (w istocie państwowym) gospodarstwie rolnym mógł kandydować do miana proletariusza. Milionom ofiar klęski głodu poświęcono aż 7 linijek tekstu (to około 1 linijka na 1 milion zmarłych), zaś w co najmniej dziesięciomilionowej migracji nędzarzy do miast dostrzegła Autorka element korzystny, bo przyczyniający się „do dynamizmu rosyjskiego uprzemysłowienia". Brakuje także spostrzeżenia, iż likwidacja NEP-u, kolektywizacja wsi, ogłoszenie pierwszego ogólnopaństwowego, kompleksowego gospodarczego planu pięcioletniego (1928-1932) - pierwszej pięciolatki, wszystko pociągało za sobą rozszerzanie penalizacji jako remedium na trudności lub opory. System stał się skrajnie represyjny i ogólnoprewencyjny ${ }^{47}$.

Na plenum KC WKP(b) w kwietniu 1929 r. Stalin mówił: „Zboża nie można uważać za zwykły towar. (...) W obecnych warunkach nadwyżki zboża w rękach kułaka są środkiem gospodarczego i politycznego wzmocnienia elementów kułackich. [...a to uzasadnia] stosowanie środków nadzwyczajnych przeciw kułactwu

${ }^{45}$ Stalin demaskował wrogów: „I brużdżą jak tylko mogą, działając podstępem” (J. Stalin, Zagadnienia leninizmu..., s. 391-392). Kiedy plany gospodarcze się nie udawały, łatwo skonstruowano długo powielany model pokazowych procesów gospodarczych, które miały dowodzić, że socjalistyczny system gospodarowania jest najlepszy na świecie, a trudności są wynikiem działania agentów imperialistycznych, dywersantów, szkodników. Takim pierwszym wielkim procesem był szachtyński proces inżynierów (1928), na który sprowadzono 100 tysięcy ludzi. Potem (1930) przyszedł jeszcze większy proces tzw. prompartii (rzekomej podziemnej Partii Przemysłowej: Promyszlennaja Partia - Prompartia), do której miało należeć 2000 inżynierów i urzędników gospodarczych, a której centrum miało znajdować się w Paryżu, na który to proces ściągnięto jeszcze większe masy robotników „spontanicznie” skandujących: „śmierć, śmierć, śmierć”. OGPU „wykryło” (1930) „kontrrewolucyjne stowarzyszenie” czterdziestu ośmiu profesorów agronomii i przetwórstwa rolnego, którzy „sabotowali” krajowe dostawy żywności. Wszyscy przyznali się do zarzutów. Wszystkich skazano na śmierć i rozstrzelano, a „proletariat gorąco dziękował chwalebnym organom OGPU, nagiemu mieczowi rewolucji, za znakomite osiągnięcia w likwidacji podstępnego spisku". Pokazowe procesy mnożyły się; zapadały drastyczne wyroki. Zob. m.in. C. Andrew, O. Gordijewski, KGB, tłum. R. Brzeski. Warszawa 1997, s. 116, passim; zob. też B. Lewickyj, Terror i rewolucja, tłum. z niemieckiego A. Palicki, przedruk II obiegu z Biblioteki „Kultury” tom CXIII [1965]. Profil, Wrocław 1990, s. 57.

${ }^{46}$ Co ciekawe, we wcześniejszej książce Sheila Fitzpatrick zauważyła, iż „naturalną postawą obywatela wobec państwa nadzorującego dystrybucję dóbr i korzyści jest postawa petenta" (S. Fitzpatrick, Życie codzienne pod rządami Stalina..., s. 333). To jest właściwy wątek, którego brak w recenzowanym eseju.

${ }^{47}$ M. Filar, W stużbie utopii. 73 lata radzieckiego prawa karnego, Toruń 1992, s. 28-29. 
(...)"48. Priorytetowa stała się likwidacja klasy kułaków i kolektywizacja. Kułakiem był nie tylko chłop bogatszy, ale także biedak chodzący do cerkwi lub po prostu przeciwny kolektywizacji. Pierwsze aresztowania głów kułackich rodzin OGPU przeprowadziło pod koniec 1929 r. - wszystkich rozstrzelano. 30 stycznia 1930 r. Biuro Polityczne KC WKP(b) podjęło decyzję o masowych przesiedleniach „kułaków”. Rozpoczęła się największa w dziejach ZSRR akcja deportacyjna $^{49}$. Rozpoczęły się gigantyczne wywózki, za koło polarne, na Syberię, gdzie pozostawiano ludzi samych sobie. Operacja wywiezienia objęła co najmniej dwa miliony ludzi ${ }^{50}$. Efektem był największy głód w historii współczesnej Europy. Porównanie z holocaustem ${ }^{51}$ jest trafne. Nazywanie tego „ekscesami kolektywizacji" (s. 191) jest po prostu fałszowaniem rzeczywistości i niehumanitarne jest użycie słowa „ekscesy” zamiast słowa „ludobójstwo”. A gdzie tu jest człowiek, pytam ja - recenzent - panią profesor z Australii? Sheila Fitzpatrick konkluduje: „Rewolucja stalinowska podporządkowała państwowej kontroli całą gospodarkę miejską i znacznie zwiększyła możliwość wyzyskiwania wsi przez państwo, Wzmocniła również aparat bezpieczeństwa i stworzyła Gułag, imperium obozów pracy, które stało się znaczącym uczestnikiem kampanii uprzemysłowienia" (s. 182-183). Przy okazji recenzent chce zaprzeczyć pewnemu stwierdzeniu Autorki i je skorygować. Autorka pisze, że w latach pierwszej pięciolatki „gospodarkę przemysłową znacjonalizowano niemal całkowicie, z wyjątkiem niewielkiego sektora spółdzielczego" (s. 188). Rzeczywistość w systemie komunistycznym (po NEP-ie) była taka, że spółdzielczość była absolutną fikcją; spółdzielnie były w istocie jednostkami państwowymi i tylko szyld fałszywie głosił, że dana jednostka to spółdzielnia. Recenzent zna to z autopsji czterdziestu pięciu lat systemu sowieckiego w Polsce.

48 J. Stalin, Dzieła, t. 12, Warszawa 1951, s. 96-97; zob. też R. Kuśnierz, Ukraina w latach kolektywizacji i Wielkiego Głodu (1929-1933), Toruń 2008, s. 35.

49 S. Ciesielski, GUŁag. Radzieckie obozy koncentracyjne 1918-1953, Warszawa 2010, s. 137 i n.; idem, Wróg jest wszędzie. Stalinowska polityka represyjna w latach 1928-1941, Toruń 2013, s. 43 i n.

${ }^{50}$ Szacunki dotyczące liczby wywiezionych są wielce rozbieżne i wahają się między 2 a ponad 10 mln ludzi. Zob. np. C. Andrew, O. Gordijewski, KGB ..., s. 119; P. Wieczorkiewicz, [w:] L. Bazylow, P. Wieczorkiewicz, Historia Rosji. Wrocław-Warszawa-Kraków 2005, s. 423; także raport zastępcy szefa OGPU - Henryka Jagody - dla Stalina z 15 października 1931, [w:] Z dziejów terroru w państwie radzieckim 1917-1953. Wybór źródet, wstęp, tłumaczenie, opracowanie J. Wojtkowiak. Poznań 2012, s. 40, także s. 33-39. Ale jeden z historyków podsumowuje: ,5 milionów rodzin, czyli około 24 milionów osób, musiało opuścić wieś. Połowa spośród nich przyczyniła się do wzrostu liczby ludności w miastach. Dwanaście milionów nie zostało nigdzie odnotowanych. Część z nich niewątpliwie zginęła”. N. V. Riasanovsky, M.D. Steinberg, Historia Rosji, tłum. A. Bernarczyk, T. Tesznar, Kraków 2009, s. 536.

${ }^{51}$ P. Wieczorkiewicz, [w:] L. Bazylow, P. Wieczorkiewicz, Historia Rosji..., s. 424. 
Sheila Fitzpatrick nie wypowiedziała słów fundamentalnych dla istoty czasów stalinowskich w ZSRR (a także w krajach satelickich po II wojnie). Nie powiedziała, że od czasów rewolucji stalinowskiej terror stał się „,normalną metodą administrowania", jak to miał stwierdzić niegdyś główny ideolog partii Nikołaj Bucharin $^{52}$, a dzisiaj powinno to być oczywiste dla każdego badającego ćwierćwiecze rządów Stalina. Oczywiste i podstawowe. Co ciekawe, Sheila Fitzpatrick w swojej wcześniejszej książce ${ }^{53}$ była o wiele bardziej zdecydowana m.in. w przedstawianiu ,czasu grozy” [to tytuł rozdziału] życia codziennego pod rządami Stalina w Rosji radzieckiej w latach trzydziestych, gdzie terror - aczkolwiek nie określony jako metoda administrowania - znalazł jednak właściwe miejsce. W omawianej tutaj syntezie-eseju o rewolucji rosyjskiej rewizjonizm zrobił duży krok naprzód.

„Rewolucja zwycięska” (to tytuł podrozdziału w rozdziale pt. „Koniec rewolucji”, s. 188 i n.) w książce związana jest z ogłoszeniem przez Stalina zakończenia budowy socjalizmu, co wnosiła ,nowa radziecka konstytucja, pierwsza od czasu rewolucyjnej konstytucji republiki rosyjskiej z 1918 roku" (s. 193). Tu omyłka Autorki, która zapomniała o konstytucji ZSRR z 1924 r., (co zauważył thumacz). To przeoczenie można darować, natomiast recenzent nie może akceptować nader poważnego traktowania treści przepisów ustawy zasadniczej z $1936 \mathrm{r}$. Słowo „gwarantowanie” przez konstytucję różnych praw pojawia się ustawicznie na kartkach książki i Sheila Fitzpatrick widzi „,doniosłość tej zmiany”. Recenzent uważa, że to nie jest poważne. Rację ma Jan Baszkiewicz, gdy pisze: „Konstytucja stalinowska była trudnym do prześcignięcia arcydziełem politycznej obłudy, zbudowanym z fikcji i przemilczeń. (...) z całą premedytacją sporządzono ustawę, która była ustrojową wioską potiomkinowską, nie z dykty wprawdzie, lecz z fasadowych fikcji prawnych" ${ }^{54}$.

Jak wspomniano na wstępie niniejszej wypowiedzi, Sheili Fitzpatrick „Ostatnie pytanie dotyczy wielkiej czystki z lat 1937-1938 - czy i ona należała do rewolucji rosyjskiej?” (s. 11). Trzeba zganić Autorkę, że pisząc o drugiej połowie lat trzydziestych w ogóle nie zajęła się formami przeprowadzania Wielkiego Terroru, tzn. prawem karnym oraz organami tzw. wymiaru sprawiedliwości. Zwłaszcza druga połowa lat 30. przyniosła dwa zjawiska z obszaru prawa karnego, a mianowicie szerokie zastosowanie prawa karnego oraz organów represji i tzw. wymiaru sprawiedliwości do wewnętrznej walki politycznej w ZSRR (procesy wielkich komunistów), po wtóre zaś dużej skali ludobójstwo z pozornym, formalnym zastosowaniem prawa karnego oraz organów represji i tzw. wymiaru sprawiedli-

\footnotetext{
52 Cyt. za C. Andrew, O. Gordijewski, $K G B \ldots$, s. 122.

53 Życie codzienne pod rządami Stalina..., s. 283, passim; zob. wyżej przypis nr 1.

54 J. Baszkiewicz, Powszechna historia ustrojów państwowych, Gdańsk 1998, s. 360-361.
} 
wości. Całkowicie poza prawem karnym, nawet poza pozorami funkcjonowania sowieckiego tzw. wymiaru sprawiedliwości, znajdują się ludobójcze akcje deportacyjne ludności z terenów okupowanych przez ZSRR na mocy realizacji paktu Ribbentrop-Mołotow, czym programowo Sheila Fitzpatrick zajmować się nie chce. Procesy wielkich komunistów zostały przez Autorkę zauważone (s. 204) w taki sposób, że gdyby nie znający sprawy czytelnik chciał się uczyć historii ZSRR z książki Sheili Fitzpatrick, to nauczyłby się, że „liderów opozycji, Lwa Kamieniewa i Grigorija Zinowjewa, skazano na śmierć za ich współudział w morderstwie Kirowa” (s. 204). Samo morderstwo Kirowa zaś to była „ekstrawagancka zbrodnia" (s. 204). Czyja? Wynika z tego logicznie, że to zbrodnia Kamieniewa i Zinowjewa. Tak się manipuluje słowami pisząc rewizjonistyczną historię. Warto przypomnieć, co napisał najwybitniejszy na świecie znawca czasów Wielkiego Terroru, brytyjski historyk Robert Conquest: „Zabójstwo Kirowa zasługuje ze wszech miar na miano zbrodni stulecia. W ciągu następnych czterech lat setki obywateli sowieckich, nie wyłączając najwybitniejszych przywódców rewolucji, zostało rozstrzelanych pod zarzutem bezpośredniej odpowiedzialności za to zabójstwo, a dosłownie miliony innych skazano na śmierć za współudział w rozległej konspiracji, która rzekomo istniała za jego kulisami. Śmierć Kirowa była faktycznie kamieniem węgielnym całego gmachu terroru i represji, dzięki któremu Stalin zapewnił sobie absolutną władzę nad społeczeństwem sowieckim"55. Natychmiast Stalin jednoosobowo ogłosił tak zwaną lex Kiro $w^{56}$ albo ,prawo z 1 grudnia" (zatwierdzone przez Biuro Polityczne 3 grudnia obiegiem). Lex Kirow drastycznie zlikwidowała wszelkie gwarancje procesowe oskarżonego. W trybie przewidzianym w lex Kirow przeprowadzono ogromną liczbę procesów politycznych, zapadały drastyczne wyroki na niewinnych ludzi, m.in. zasłużonych bolszewików. Lex Kirow obowiązywała do kwietnia 1956 r.; została uchylona dopiero po rewelacyjnym referacie Chruszczowa na XX Zjeździe KPZR.

Jan Baszkiewicz dosadnie i jakże trafnie określił komunizm jako najbardziej zakłamany w historii ludzkości system, który coraz bezczelniej poszerzał przepaść między fasadą a rzeczywistością ${ }^{57}$. Dodać trzeba zdecydowanie, iż w to kłamstwo wpisywała także działalność organów ścigania, prokuratury, sądów. W „totalne kłamstwo” (Leszek Kołakowski) wpisywało się m.in. tzw. wymierzanie sprawiedliwości, będące $\mathrm{w}$ istocie częścią totalitarnego terroru. Jak już wielokrotnie wskazywałem ${ }^{58}$, gigantyczny w liczbach unicestwianych ludzi terror

${ }^{55}$ R. Conquest, Wielki terror, thum. W. Jeżewski, Warszawa 1997, s. 49.

56 Piszę o tym szczegółowo, cytując pełny tekst, w: A. Lityński, Prawo Rosji i ZSRR 1917$1991 \ldots$, s. 210-211, zob. też s. 176, 220, 223, 382.

57 J. Baszkiewicz, Powszechna historia ustrojów państwowych, Gdańsk 1998, s. 356.

${ }^{58}$ M.in. zob. A. Lityński, Komunizm a prawo (przypadek RSFRR i ZSRR), [w:] B. Garczyk, P.P. Repczyński (red.), Rok 1917 w Rosji: carat - rewolucja - nowa rzeczywistość. Szkice i studia, 
komunistyczny, zwłaszcza drugiej połowy lat 30. w ZSRR, jeśli miał przybierać pozory wymierzania sprawiedliwości, musiał zastosować metody, które z cywilizowanymi formami wymiaru sprawiedliwości w XX wieku nie mogły mieć nic wspólnego. Ludobójczy terror tego okresu realizowano głownie w trybie administracyjnym, przez kolegium specjalne OGPU-NKWD, tzw. OSO ${ }^{59}$, zaś w terenie tak zwane „trojki” lub „dwojki”, w „trybie albumowym” ${ }^{60}$ - jak to nazywano w ówczesnym żargonie sowieckiej bezpieki. Represje były objęte centralnym planowaniem - ustalano kontyngenty dla rejonów, a więc centralnie przewidywano, ile ma być kar śmierci, ile zaś skazań na długoletni łagier. W roku 1937 aż 87\% skazanych było ofiarami trojek i dwojek NKWD ${ }^{61}$. To właśnie w 1937 r. przeprowadzono tzw. „operacje narodowościowe”, będące najbardziej klasycznym ludobójstwem: zabijano masowo ludzi dlatego, że byli określonej narodowości. Pierwszą, największą i wzorcową dla sowieckiej bezpieki była „operacja polska" ${ }^{2}$. Była to największa jednorazowa akcja ludobójstwa Polaków w całych tysiącletnich dziejach Polski. W drugiej połowie lat 30. tylko niewielki odsetek spraw trafiał do tak zwanego sądu. Przed Kolegium Wojskowym Sądu Najwyższego rozprawa trwała średnio 10 minut $^{63}$. Przecież to wódz rewolucji - Lenin - w 1922 r. (a to okres NEP-u) napominał Dymitra Kurskiego, ludowego komisarza sprawiedliwości, że „sąd nie powinien uchy-

„Poznańskie Studia Wschodnioznawcze” 2019, nr 13, s. 272, passim; idem, Prawo Rosji i ZSRR $1917-1991 \ldots$, s. 212.

${ }^{59}$ Особое совещание $=$ osoboje sowieszczanie.

${ }^{60}$ Albumy to zwykłe spisy przeznaczonych do zagłady, wykonywane przez pojedynczych funkcjonariuszy bezpieki, a zatwierdzane - podpisywane później (bez czytania) przez upoważnioną trojkę lub dwojkę. Żadnej możliwości odwołania od takiej zaocznej decyzji nie było.

${ }^{61}$ S. Ciesielski, Wróg jest wszędzie ..., s. 222-223; B. Garczyk, Radziecka polityka narodowościowa w latach 1917-1941 na przykladzie Piotrogrodu-Leningradu, Poznań 2011, s. 156.

${ }^{62} \mathrm{~W}$,operacji polskiej” ludobójstwa dokonano na co najmniej 140 tysiącach Polaków-obywateli ZSRR, ale szacując liczby zmarłych żon i dzieci, trzeba tę wielkość w przybliżeniu podwoić. Do tego trzeba dodać nieznaną liczbę komunistów polskich, którzy dobrowolnie przybyli do ZSRR. Nieco więcej o tym zob. N. Iwanow, Zapomniane ludobójstwo. Polacy w państwie Stalina. „, Operacja polska” 1937-1938, Kraków 2014, passim; B. Garczyk, Radziecka polityka narodowościowa..., s. 154, 167, passim; A. Lityński, Ludobójstwo: operacja polska NKWD (1937-1938). Uchwała Biura Politycznego KC WKP(b) oraz rozkazy szefa NKWD ZSRR, „Studia Iuridica Lublinensia”, t. XIX poświęcony pamięci Profesora Mariana Lecha Klementowskiego (1943-2013), pod red. M. Kuryłowicza i W. Witkowskiego, Lublin 2013, s. 181-199.

${ }^{63}$ Według sprawozdania złożonego przez przewodniczącego tego Kolegium, Wasilija Ulricha, w ciągu 2 lat (październik 1936 - październik 1938) Kolegium orzekło 30514 kar śmierci i 5643 wyroki pozbawienia wolności, czyli średnio po 60 wyroków dziennie, licząc pracę nieprzerwanie przez 6 dni w tygodniu. P. Wieczorkiewicz, Uwagi o działalności sowieckiego aparatu sprawiedliwości i systemu śledczego w dobie wielkiej czystki, [w:] K. Rokicki (red.), Departament X MBP - Wzorce, struktury, działanie, Warszawa 2007, s. 25; zob. też A. Lityński, Prawo Rosji i ZSRR 1917-1991 ..., s. 331. 
lać się od stosowania terroru" ${ }^{4}$. Na XX zjeździe KPZR Chruszczow ujawnił: „Przyjęła się występna praktyka polegająca na tym, że w NKWD sporządzano wykazy osób, których sprawy podlegały rozpatrzeniu przez Kolegium Wojskowe i z góry ustalano wymiar kary”65. „,...) kto pokładał ostatnią nadzieję w instytucjach prawa, musiał doświadczyć tego, że każda z tych instytucji zwracała się przeciwko niemu, stanowiąc część sieci terroru i gnębienia" ${ }^{66}$. Szczególnie dużo „wrogów ludu” znajdowano w partii, NKWD, Armii Czerwonej ${ }^{67}$, ponieważ zgodnie z odkrywczą myślą Stalina - w miarę postępów budownictwa socjalizmu walka klasowa się zaostrza. Po II wojnie światowej wzorce sowieckie bardzo ściśle przenoszono do krajów satelickich. Podzielam pogląd, że „,...) zbrodnia jest jednym z elementów właściwych całemu systemowi komunistycznemu podczas całego jego istnienia" ${ }^{68}$. W książce Sheili Fitzpatrick zbrodni jednak nie widać; są tylko niekiedy „ekscesy” Stalina.

Szkoda, że Autorka nie ma już zapewne możliwości, by porozmawiać z heroicznymi lotnikami australijskimi, którzy ochotniczo (!) latali z Brindisi (,obcas włoskiego buta") nad walczącą w Powstaniu Warszawę, by dokonywać zrzutu dla powstańców. Ciężkie i w rezultacie powolne były samoloty zabierające broń dla powstańców i musiały lecieć nad całą okupowaną przez Niemców Europą, wymijając ogień artylerii przeciwlotniczej i szybkich samolotów myśliwskich wroga. W dodatku samoloty z Brindisi musiały zabierać zapas paliwa na drogę w obie strony, ponieważ stojący na prawej stronie Wisły sowieci nie pozwalali lądować na ich lotniskach nawet dla nabrania paliwa. Stalin zatrzymał ofensywę Armii Czerwonej, by się przypatrywać jak Hitler rozprawia się z Powstaniem Warszawskim. Przynajmniej starsze pokolenie Polaków pamięta heroizm lotników australijskich. I pamięta zbrodnie Stalina od 17 września 1939 r. poczynając.

1 września 2019 r. w Warszawie odbyło się spotkanie kilkudziesięciu liderów politycznych świata z okazji 80 rocznicy rozpoczęcia II wojny światowej. Do tej

${ }^{64}$ Lenin do Dymitra Kurskiego 7 maja 1922 r. W.I. Lenin: Dzieła wszystkie, t. 45, Warszawa 1989, s. 188.

${ }^{65}$ N.S. Chruszczow, O kulcie jednostki i jego nastęstwach. Referat I sekretarza KC KPZR tow. N.S. Chruszczowa na XX Zjeździe KPZR 25 lutego 1956 [tyt. oryg. O культе личности и его последствиях. Доклад Первого секретаря ЦК КПСС Н. С. Хрущева], [b.m.d.], s. 20.

${ }^{66}$ Amerykański Trybunał Wojskowy w wyroku z 4 grudnia 1947 r. w tzw. sprawie prawników; cyt. za W. Kuleszą, Crimen laesae iustitiae. Odpowiedzialność karna sędziów i prokuratorów za zbrodnie sądowe wedtug prawa norymberskiego, niemieckiego, austriackiego i polskiego, Łódź 2013, s. 40.

${ }^{67}$ To była hekatomba niemal porównywalna ze stratami oficerów Armii Czerwonej w II wojnie światowej: utracono prawie połowę generałów i oficerów w stopniu powyżej pułkownika, ,armia została zgilotynowana”. P. Wieczorkiewicz, Łańcuch śmierci. Czystka w Armii Czerwonej 19371939, Warszawa 2001, s. 1079, zob. też s. 73, passim.

${ }^{68}$ S. Courtois, [w:] Czarna księga komunizmu. Zbrodnie, terror, prześladowania, tłum. zespół, wstęp do polskiego wydania K. Kersten, Warszawa 1999, s. 25. 
wojny przyznają się i przepraszają Niemcy, ale nie przyznają się i nie przepraszają Rosjanie, którzy wszak wspólnie z III Rzeszą wojnę tę wszczęli. Główne przesłanie spotkania warszawskiego to Pamięć i przestroga. Warto, aby Sheili Fitzpatrick też to hasło przyświecało.

Należy przyznać rację Hannah Arendt, kiedy pisze: „(...) żaden historyk nie zdoła nigdy spisać opowieści o naszym własnym stuleciu [XX -A.L.] bez osnucia jej „na wątku rewolucji” $(\ldots)^{69}$.

Natomiast Sheila Fitzpatrick konkluduje m.in.: „Rewolucja rosyjska pozostawiła także skomplikowane globalne dziedzictwo. Była wielką rewolucją $\mathrm{XX}$ wieku, symbolem socjalizmu, antyimperializmu i odrzucenia dawnego porządku w Europie" (s. 212). Recenzent musi temu zaprzeczyć i twierdzi, że wprawdzie rewolucja rosyjska pozostawiła skomplikowane globalne dziedzictwo, ale była symbolem nie socjalizmu, lecz totalitaryzmu i „,czerwonego” imperializmu, co narody Europy Wschodniej odczuły nad wyraz boleśnie. Była symbolem ludobójstwa na skalę niespotykaną, symbolem zmarnowanego życia i cierpień dziesiątków milionów ludzi. Byłaby poważnym zagrożeniem dla dorobku całej naszej cywilizacji, gdyby pakt Ribbentrop-Mołotow nie został przez III Rzeszę złamany. Rewizjonistyczna książka tego nie zmieni, nawet jeśli jest ładnie skonceptualizowana i napisana ładnym językiem.

${ }^{69}$ H. Arendt, O rewolucji, tłum. M. Godyń, Kraków 1991, s. 259. 